\title{
Transfusion practices in obstetrics and gynaecology in a tertiary care center
}

\author{
Shashi Singh, Parul Sinha*, Gunjan Yadav, Uma Gupta, Priyanka Tyagi
}

Department of Obstetrics \& Gynaecology, Era's Lucknow Medical College \& Hospital, Lucknow, UP, India

Received: 20 January 2016

Revised: 17 February 2016

Accepted: 22 February 2016

\section{*Correspondence:}

Dr. Parul Sinha,

E-mail: drparuland@gmail.com

Copyright: ( $)$ the author(s), publisher and licensee Medip Academy. This is an open-access article distributed under the terms of the Creative Commons Attribution Non-Commercial License, which permits unrestricted non-commercial use, distribution, and reproduction in any medium, provided the original work is properly cited.

\begin{abstract}
Background: This study was an effort to identify and highlight existing transfusion practices in our hospital, including the indications of various blood components used and the allergic reaction encountered. Obstetric hemorrhage remains major cause of maternal mortality worldwide and Blood transfusion can be a lifesaving intervention.

Methods: This was a prospective cross- sectional study conducted on 172 patients who underwent blood and blood component transfusion. $\mathrm{Hb}$ concentration $<7 \mathrm{~g} / \mathrm{dL}$ was determined to be an indication for blood product transfusion.

Results: In this study the most common indication for blood transfusion was antenatal patient with anemia (32.8\%) followed by ruptured ectopic pregnancy (19.5\%) and postpartum hemorrhage (18.8\%). Amongst gynecological patients, the most common cause for transfusion was abnormal uterine bleeding (AUB) (61.4\%). Majority patients were given single unit transfusion. Adverse reactions found in our study were not statistically significant.

Conclusions: Therefore this study concludes that we still need to go a long way in order to train the medical fraternity at all levels to learn to identify the valid indications for transfusion and select appropriate component for management.
\end{abstract}

Keywords: Blood transfusion, Blood component therapy, Obstetric hemorrhage

\section{INTRODUCTION}

This study was an effort to identify and highlight existing transfusion practices in our hospital, including the indications of various blood components used and the allergic reaction encountered. Blood transfusion can be a lifesaving intervention. Obstetricians and gynaecologists need to be aware of the potential complications of blood transfusion and the appropriate use of blood transfusion in their practice. ${ }^{1}$ Obstetricians and gynaecologists utilize a large number of blood units. Anaemia is common during pregnancy. During the last trimester of pregnancy, platelets are activated, fibrinolytic system is suppressed and there is an increased susceptibly to thrombocytopenia. Hence the mother faces a risk of significant haemorrhage; particularly during labour. ${ }^{2}$ Obstetric haemorrhage remains major cause of maternal mortality worldwide. WHO estimates, over a thousand of all maternal deaths are directly due to obstetric haemorrhage. The obstetric conditions leading to haemorrhage are placenta praevia, placental abruption and postpartum haemorrhage. Massive haemorrhage typically appears in postpartum. The blood flow to the placenta is about $700 \mathrm{ml} / \mathrm{min}$ at term, so bleeding is likely to be rapid, often unexpected and difficult to control. Transfusion of blood and its components is a potentially lifesaving procedure. Although meticulous care is taken in the selection of blood donors, processing, storage and transfusion of blood products, serious transfusion related complications may ensue. It is the incumbent on the 
physician to be sure that a blood product is indicated, and standard transfusion practices are observed. ${ }^{3}$ Each hospital must take into account the resources available within its own institution and community to design a protocol that will assist them in the optimal management of obstetrical haemorrhage. ${ }^{4}$

\section{METHODS}

This was a prospective cross- sectional study conducted on 172 patients who underwent blood and blood component transfusion, admitted in the Obstetrics \& Gynecology ward of Era's Lucknow Medical College \& hospital. The study period was 13 months, from August 2013 to September 2014. Blood products involved in this study were red cells concentrates (RCC), fresh-frozen plasma (FFP), and platelet concentrates (PC). Hemoglobin $(\mathrm{Hb})$ concentration necessary to maintain appropriate hemodynamics and oxygen supply is $\geq 7$ $\mathrm{g} / \mathrm{dL}, \mathrm{Hb}$ concentration $<7 \mathrm{~g} / \mathrm{dL}$ was determined to be an indication for blood product transfusion. In addition to this, the patient's age, medical condition, state of hemorrhage, and blood test data were taken into consideration. Since the transfusion for patients with an $\mathrm{Hb}$ concentration $\geq 7 \mathrm{~g} / \mathrm{dL}$ and stable vital signs may lead to excessive transfusion, RCC transfusion was performed with a goal $\mathrm{Hb}$ concentration of $7-8 \mathrm{~g} / \mathrm{dL}$. FFP was concomitantly transfused until the coagulation function normalizes. The following items were evaluated: underlying disorders which required blood product transfusion, types of blood product and their transfused volume, blood transfusion reactions and data of hemoglobin $(\mathrm{Hb})$ concentration.

\section{RESULTS}

Maximum women (148 subjects-86\%) were in reproductive age group. Majority of patients requiring blood transfusion were urban $(53.5 \%)$ and of rest were rural $(46.5 \%)$. Socioeconomic status of $39 \%$ was class III and $43 \%$ were of class II. Figure 1 depicts grades of anemia at time of admission. Most common blood group was $\mathrm{B}^{+}(37.2 \%)$, followed by $\mathrm{O}^{+}(30.2 \%), \mathrm{A}^{+}(26.7 \%)$ while $\mathrm{AB}^{+}(5.2 \%)$ and $\mathrm{O}$-ve $(0.6 \%)$ were less common blood groups.

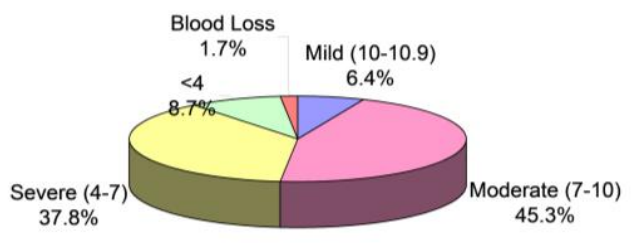

Figure 1: Grades of anaemia on admission.

Out of 172 patients, $128(74.4 \%)$ were admitted for obstetric treatment. Most common indication for blood transfusion was ANC with anaemia (32.8\%) followed by ruptured ectopic pregnancy (19.5\%), PPH (18.8\%) (Table 1).

Table 1: Blood transfusion in obstetric cases $(n=128)$.

\begin{tabular}{|lll|}
\hline Obstetric problems & Frequency & Percent \\
\hline ANC + anaemia & 42 & 32.8 \\
\hline Twin pregnancy & 4 & 3.1 \\
\hline APH & 8 & 6.3 \\
\hline Missed abortion & 2 & 1.6 \\
\hline Incomplete abortion & 13 & 10.2 \\
\hline Rupture uterus & 2 & 1.6 \\
\hline Rupture ectopic & 25 & 19.5 \\
\hline PPH & 24 & 18.8 \\
\hline Obstetric Hysterectomy & 4 & 3.1 \\
\hline Puerperal Sepsis & 4 & 3.1 \\
\hline
\end{tabular}

Of all women requiring transfusion forty four $44(25.6 \%)$ were admitted for gynaecological treatment. Most common cause for transfusion was abnormal uterine bleeding (AUB) (61.4\%), followed by puberty menorrhagia $(18.2 \%)$ while myomectomy, foreign body (6.8\% each) and carcinoma $(2.3 \%)$ (Table 2) were other causes for blood transfusion.

Table 2: Blood transfusion in gynecological cases $(n=44)$.

\begin{tabular}{|lll|}
\hline Gynaecological problems & Frequency & Percent \\
\hline Puberty menorrhagia & 8 & 18.2 \\
\hline AUB & 27 & 61.4 \\
\hline $\begin{array}{l}\text { Vulval hematoma } / 3^{\circ} \text { perineal } \\
\text { tear }\end{array}$ & 2 & 4.6 \\
\hline Cho. Carcinoma & 1 & 2.3 \\
\hline Myomectomy & 3 & 6.8 \\
\hline Foreign body & 3 & 6.8 \\
\hline
\end{tabular}

In the present study, maximum numbers of patients were given single unit transfusion. Amongst those receiving whole blood, $62.1 \%$ received single unit and $57.0 \%$ of those receiving packed cells were given single unit transfusion (Table 3).

Table 3: Type and number of transfusion $(n=172)$.

\begin{tabular}{|lllllll|}
\hline $\begin{array}{l}\text { Units } \\
\text { trans- }\end{array}$ & \multicolumn{2}{l}{$\begin{array}{l}\text { Whole blood } \\
(\mathrm{n}=141)\end{array}$} & \multicolumn{2}{l}{$\begin{array}{l}\text { Packed cells } \\
(\mathrm{n}=100)\end{array}$} & FFP $(\mathrm{n}=7)$ \\
fused & No. & $\%$ & No. & $\%$ & No. & $\%$ \\
\hline 1 & 88 & 62.41 & 57 & 57.0 & - & - \\
\hline 2 & 38 & 26.95 & 38 & 38.0 & 4 & \\
\hline 3 & 9 & 6.38 & - & - & - & - \\
\hline 4 & 4 & 2.83 & 5 & 5.0 & 3 & 42.9 \\
\hline 5 & 1 & 0.70 & - & - & - & - \\
\hline 6 & 1 & 0.70 & - & - & - & - \\
\hline & & 100 & 100 & 100 & 7 & 100 \\
\hline
\end{tabular}

No adverse reaction was found in majority of patients of above three types of transfusions but proportion of 
reaction was higher in fresh frozen plasma (FFP) $(28.6 \%)$ as compared to that in Whole blood $(5.6 \%)$ and packed cell $(9.0 \%)$. Difference in proportion of adverse reactions was not found to be statistically significant $(\mathrm{p}=0.068)$ (Table 4).

Table 4: Blood transfusion reaction.

\begin{tabular}{|lllllll|}
\hline & \multicolumn{2}{l}{$\begin{array}{l}\text { Whole } \\
\text { Blood } \\
\text { Reaction }\end{array}$} & \multicolumn{2}{l}{$\begin{array}{l}\text { Packed } \\
\text { cells }\end{array}$} & \multicolumn{2}{l|}{$\begin{array}{l}\text { Fresh frozen } \\
\text { plasma }\end{array}$} \\
& No. & $\%$ & No. & $\%$ & No. & $\%$ \\
\hline $\begin{array}{l}\text { No } \\
\text { reaction }\end{array}$ & 133 & 94.4 & 91 & 91.0 & 5 & 71.4 \\
\hline Reaction & 8 & 5.6 & 9 & 9.0 & 2 & 28.6 \\
\hline
\end{tabular}

\section{DISCUSSION}

In developing countries obstetric complications are leading indications of transfusion. Blood transfusion is recognized as one of the eight essential components of comprehensive emergency obstetric care, which has been shown to reduce maternal mortality. ${ }^{5}$ In our observation whole blood was transfused in 141 subjects $(82 \%)$, and 100 women with RCC (55\%). Gupte S et al observed $60 \%$ of whole blood usage in obstetric practice. The $\mathrm{Hb}$ concentration of anemia ranged from $1.5 \mathrm{gm} / \mathrm{dl}$ to $13 \mathrm{~g} / \mathrm{dl}$ (Figure 1), about $25 \%$ had $\mathrm{Hb}$ level more than $8 \mathrm{gm} / \mathrm{dl}^{2}{ }^{2} \mathrm{In}$ our study anaemia is more common in reproductive age group, less common in preschool and school going children which is same in the study done by Saxtan $\mathbf{J}$ et al and Oliveria $\mathrm{M}$ et al. ${ }^{6,7}$ In European journal of clinical nutrition higher SES leads to lower prevalence of anemia. In our study class 2 and class 3 women suffer more from anemia.

In Korean nutritional society anemia in lower maternal education group was $14.9 \%$ and in higher maternal education group was $7.8 \%$ whereas in our study $66.8 \%$ were of uneducated to lower educated group and $9.3 \%$ were in higher educated group of women.

In our study single unit whole blood was given in (88/141) $62.4 \%$ \& (Table 3 \& 4) RCC were given in (57/100) $57 \%$. Vachhani et al observed that single unit transfusion has not declined much and have reported it to be $15.12 \%$. Incidence of single unit transfusion in Obstetrics and Gynecology is much more as reported and this was also evident in our study as opposed to Vachhani et $\mathrm{al}^{8}$ WHO strongly discourages single unit transfusion. ${ }^{9}$ Gupte and Shaw ${ }^{10}$ have observed maximum use $(62.2 \%)$ of single unit transfusions in urological surgeries and minimum $(25.8 \%)$ in cancer surgeries performed on adult patients.

There is now increased awareness about component use for management of obstetric and gynecological hemorrhage. Studies have shown that significant bleeding in the post-partum period or/menorrhagia from menarche may be due to systemic haemostatic defect. ${ }^{11}$ Obstetric bleeding particularly DIC in the post-partum period requires components like RBC, platelets, FFP and Cryoprecipitate. According to Mercier and Bonnet ${ }^{12}$ it is reasonable to use blood products like FFP, PC to control acute obstetric hemorrhage. They recommend the use of fibrinogen concentrate if plasma fibrinogen level is below $1 \mathrm{~g} / \mathrm{L}$ and emphasize that data on proactive administration of platelets is insufficient to recommend routine use of platelets. The recombinant factor VIIa is advocated only after failure of other conventional therapies. Singi et $\mathrm{al}^{13}$ have recommended recombinant factor VII a, 20-80 $1 \mathrm{~g} / \mathrm{kg}$ in severe cases of postpartum hemorrhage. The purpose of a RCC transfusion is to restore oxygen carrying capacity in order to maintain adequacy of tissue oxygenation. ${ }^{14,15}$ Maintaining adequate tissue oxygenation in the face of acute blood loss is a function of partial pressure of inspired oxygen, pulmonary gas exchange, and oxygen delivery to the blood, cardiac performance, tissue oxygen demands and red cell oxygen content. The normal adult tolerates a $10-15 \%$ acute decrease in blood volume well. Once blood loss has reached $40 \%$ a sequence of physiologic changes whose purpose is to maintain tissue oxygenation rapidly comes into play. ${ }^{16}$ Deciding when red cell transfusion is necessary to maintain adequate tissue oxygenation in the face of acute hemorrhage is an extremely difficult task. Acute obstetric blood loss is usually unpredictable, sudden, and voluminous, and therefore occurs under circumstances where sophisticated measurements of physiologic parameters are usually unavailable. The obstetrician must decide whether or not to transfuse based on observation of simple parameters such as heart rate, blood pressure, respiratory rate, and persistence of bleeding.

\section{CONCLUSIONS}

Acute obstetric blood loss is usually unpredictable, sudden, and voluminous and deciding when red cell transfusion is necessary to maintain adequate tissue oxygenation in the face of acute haemorrhage is an extremely difficult task. Overall incidence of blood component utilization has significantly increased in the recent years, but still the use of whole blood is preferred by many clinicians because of its easy availability in the blood banks. WHO strongly criticizes the use of single unit transfusion. According to WHO, the four cornerstones of a safe and effective blood donor service are a national system, volunteer donations, blood testing and avoidance of unnecessary transfusions. Therefore we still need to go a long way in order to train the medical fraternity at all levels to learn to identify the valid indications for transfusion and select appropriate component for management.

\section{Funding: No funding sources}

Conflict of interest: None declared

Ethical approval: The study was approved by the Institutional Ethics Committee 


\section{REFERENCES}

1. Ekeroma A, Ansari A, Stirrat G. Blood transfusion in obstetrics and gynecology. BJOG. 2005;104(3):27884.

2. Gupte SC, Patel F, Patel P. Blood transfusion practice in obstetrics and gynecology. J Obstet Gynecol Ind. 2004;54(2):187-90.

3. David A. Sacks blood component replacement. Crit Care Obstetr. $5^{\text {th }}$ edition. Hobken:NJ WileyBlackwell; 2010:165-180.

4. Deshpande S, Gadappa S, Yelikar K. Blood and blood components therapy in obstetrics and gynecology-a review. Indian J Res. 2014;3:(7).

5. Obaid TA. No woman should die giving life. Lancet. 2007;370:1287-8

6. Saxtan J, Carnell S, Van Jaarsveld C, Wardle J. Maternal education is associated with feeding style. JAM Diet Assoc. 2009;109:894-8.

7. Oliveira M, Osorio M, Raposo M. Socioeconomic and dietary risk factors for anemia in children aged 6 to 59 months. J Pediatr (RioJ). 2007;83:39-46.

8. Vachhani JH, Joshi JR, Bhanvadia VM. Rational use of blood: a study report of single unit transfusion. Indian J Hematol Blood Transfus. 2008;24:69-71.

9. WHO Blood Safety Handbook (2001) the clinical use of blood. WHO/BTS/99.3,Geneva; 2001:122-34.

10. Gupte SC, Shaw A. Evaluation of single unit red cell transfusions given to adults during surgery. Asian J Transfus Sci. 2007;1:12-5.
11. Agarwal MB. Menorrhagia: haematologists point of view. Indian J Hematol Blood Transfus. 2003;21(2):29-33.

12. Mercier FJ, Bonnet MP. Use of clotting factors and other prohemostatic drugs for obstetric hemorrhage. Curr Opin Anaesthesiol. 2010;23:310-6.

13. Singi SR, Fernandez E, Pandya ST, Badrinath HR. Recombinant factor VIIa: use in fatal post-partum hemorrhage-Indian experience case series and review of literature. Indian J Hematol Blood Transfus. 2009;25:1-5.

14. Brecher ME. American association of blood banks. Technical manual. $15^{\text {th }}$ edn. Bethesda, MD: AABB, 2005.

15. Simon TL, Alverson DC, AuBuchon J, Cooper ES, DeChristopher PJ, Glenn GC et al. Practice parameter for the use of red blood cell transfusions. Arch Pathol Lab Med. 1998;122:130-8.

16. Hofmeyr GJ, Mohala BKF. Hypovolemic shock. Best Pract Res Clin Obstet Gynaecol. 2001;15:64562.

Cite this article as: Singh S, Sinha P, Yadav G, Gupta U, Tyagi P. Transfusion practices in obstetrics and gynaecology in a tertiary care center. Int $\mathbf{J}$ Reprod Contracept Obstet Gynecol 2016;5:831-4. 